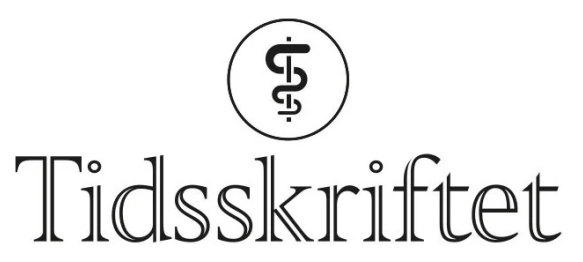

DEN NORSKE LEGEFORENING

\title{
Otto Waldemar Steenfeldt-Foss
}

\author{
MINNEORD \\ PER VAGLUM \\ FINN STENSTAD \\ BJØRN GUNBY
}

JON RUD

TORE GUDE

En bauta i norsk og internasjonal psykiatri har forlatt oss. Otto Steenfeldt-Foss sovnet stille inn 17. august $i$ år i en alder av nesten 90 år.

Otto ble født i Oslo 27.10.1931. Etter videregående skole studerte han i Sveits og tok medisinsk embetseksamen i 1957. Sin psykiatriske karriere startet han på Dikemark sykehus i 196o Der var han en drivende kraft i rehabiliteringsprogrammer for kronisk psykotiske pasienter som hadde blitt forpleiet i sykehjem eller privat omsorg over lang tid.

I årene 1968-69 var han WHO-fellow ved Harvard University, deretter hadde han stilling i Helsedirektoratet under Karl Evang, før han ble tilsatt som assisterende overlege på Psykiatrisk avdeling B ved Ullevål sykehus. Etter dette bekledde han i seks år stilling som Statens overlege i psykiatri i Helsedirektoratet. Der så han behovet for en reorganisering av omsorgen for de farlige psykiatriske pasientene. Dette rakk han ikke å fullføre før Reitgjerdet-skandalen.

I 1981 ble han administrerende overlege ved Studentenes helsetjeneste ved Universitetet i Oslo, der han ble til pensjonsalder i 2001. Han fungerte både som psykiater og allmennpraktiker, idet han allerede hadde kvalifisert seg til spesialiteten i allmennmedisin og sosialmedisin, i tillegg til psykiatri.

Han har i mange år kjempet for psykiatriske pasienters verdighet og menneskerettigheter, og for det mottok han både nasjonale og internasjonale hedersbevisninger. I 2002 ble han slått til Ridder av St. Olavs orden, og i 2005 ble han tildelt den prestisjetunge Jean Delayprisen for sin helhjertede innsats for bedring av menneskerettighetene innen psykiatrien i internasjonal målestokk. World Psychiatric Association omtaler selv prisen som psykiatriens nobelpris. 
Hans mange verv var bl.a. medlem av Legeforeningens landsstyre, leder av Norsk psykiatrisk forening, leder av Legeforeningens psykoterapiutvalg, leder av Legeforeningens menneskerettighetsutvalg og leder av det første stimuleringsprogrammet for norsk psykiatrisk forsking.

«I vårt arbeid er vi først og fremst til for våre pasienter», var et motto han fulgte hele sitt yrkesaktive liv.

Otto Steenfeldt-Foss etterlater seg et tomrom i sitt vidstrakte nettverk, både innen fagkretser og sosialt. Vi kolleger som har stått han nær, har lært han å kjenne som en god og trofast venn med et kunnskapsforråd og en livserfaring som går utenpå det meste.

Våre tanker går til hans nærmeste familie, og vi lyser fred over hans minne.

Publisert: 11. oktober 2021. Tidsskr Nor Legeforen. DOI: 10.4045/tidsskr.21.0642

(C) Tidsskrift for Den norske legeforening 2023. Lastet ned fra tidsskriftet.no 26. april 2023. 